\title{
METHODS OF SMUGGLING OF FIREARMS AND AMMUNITION IN THE STRUCTURE OF CRIMINALISTIC CHARACTERISTICS
}

\author{
ORCID ID: 0000-0001-8058-3071 \\ Viktor Shevchuk \\ Doctor of Legal Sciences, Professor, \\ Honored Lawyer of Ukraine, Professor of Criminalistics of the \\ Yaroslav Mudryi National Law University
}

Mykhailo Kotiuk

Magister of the 5 course 1 group of the Juridical Personnel Training Institute for the Security Service of Ukraine Yaroslav Mudryi National Law University

UKRAINE

\begin{abstract}
The topical problems of the methodics of investigation of smuggling of firearms and ammunition, in particular the process of smuggling such criminal offenses in the structure of criminalistic characteristics, are identified, promising areas of scientific research in this field of knowledge are identified and outlined. It is noted that the generalization of the practice of investigation indicates that the investigative and operational-search bodies face serious difficulties in detecting and investigating this category of criminal offenses. It is substantiated that such circumstances necessitate the development of methodological bases, theoretical and practical recommendations that could increase the effectiveness of law enforcement agencies to detect and detect such crimes. Perspective directions of criminalistic researches of a technique of investigation of smuggling are considered.
\end{abstract}

Formulation of the problem. The current period of formation of the rule of law in Ukraine is characterized by the aggravation of the general criminal situation associated with the deepening economic, social and political crisis in society. This, in turn, led to a significant increase in the smuggling of firearms, ammunition and explosives (Article 201 of the Criminal Code of Ukraine). Given the increased social danger of these criminal phenomena, such crimes are one of the factors threatening the national security of Ukraine. Smuggling of weapons, ammunition and explosives harms the public safety of the Ukrainian people, human health, as well as Ukraine's international cooperation with other states in the fight against this type of organized crime $[1 ; 2 ; 3]$.

According to some experts, $70 \%$ of seized weapons in Ukraine are smuggled; that is why the problem of blocking the channels of arms smuggling into the country is relevant today. The main ways of moving weapons and ammunition across the customs border of Ukraine are: a) international rail service, when weapons and ammunition are detected during customs control of trains; b) international road transport; c) international maritime transport; d) other modes of transport. Sources and channels of supply of weapons and ammunition to smugglers, as a rule, are: a) theft of weapons from military units and bases; b) theft of individual parts and mechanisms in armed factories; c) import of weapons from the CIS countries (Russian Federation), Transnistria, Dagestan, the North Caucasus, from places of armed conflict; d) acquisition on the territory of Ukraine from strangers; e) areas of 
military shooting ranges, training grounds, places of past hostilities, where weapons were found; f) handicrafts in underground workshops, etc.

Sources of acquisition of firearms and ammunition are mainly limited to regions where international armed conflicts have arisen in recent years. Therefore, most smuggled weapons are seized in regions directly bordering areas of recent armed conflict. For example, in the border areas with the Russian Federation, Moldova. This is due to the fact that the border area in the customs area of such regions has access to the ATO area, the territory of the armed conflict, it borders with Transnistria, the Republic of Moldova and Russia, which are currently the main base for the accumulation of firearms, ammunition and explosives[4; 5].

Presenting main material. The generalization of the practice of investigating the smuggling of firearms and ammunition indicates that the investigative and operational-search bodies face serious difficulties in detecting and investigating this category of crimes. All of the above necessitates the development of methodological bases, theoretical and practical recommendations that could increase the effectiveness of law enforcement agencies to detect and detect such crimes $[6 ; 7 ; 8]$. Of particular relevance are studies of ways to smuggle firearms and ammunition as part of the criminalistic characteristics of this type of crime.

The method of smuggling firearms and ammunition is a deterministic system of criminal actions to prepare, execute and conceal the illegal movement of such contraband items across the customs border, as well as to use the results of this activity. Today, the most common ways of committing the crimes under investigation are: a) movement of firearms and ammunition outside customs control; b) movement by concealment from customs control. Consider them.

The movement of firearms and ammunition outside customs control covers various actions of the smuggler to move weapons and ammunition outside the places specified by the customs authorities of Ukraine (customs, customs posts) or outside the established time for customs control. In this case, it does not matter whether the offender used any means of concealing objects or not. Most often, such movement is carried out by bypassing customs posts by cars and trucks. In such cases, in order to evade customs control, smugglers, as a rule, do not use traditionally existing highways, but roads (field, steppe, interurban), bypass roads. In practice, there are far fewer cases of smuggling bypassing pedestrian customs control points. At the same time, a variety of tricks are used to bypass customs control points, for example, smuggling firearms with the help of a flight attendant by bypassing the customs inspection zone.

Ways of smuggling firearms and ammunition by hiding from customs control are the most common group of ways to commit this type of smuggling. Concealment of these contraband items from customs control is any method of concealment that complicates their detection, in particular: with the use of caches or other means of "physical concealment" that make it difficult to visually detect contraband; by giving some objects the appearance of others; by submitting to the customs authority as a basis for moving items of forged documents or those obtained illegally, contain false information or are grounds for moving other items. Basically, in practice, there are three ways to hide firearms and ammunition from customs control: a) hiding places; b) other methods of "physical concealment" that complicate the visual detection of smuggling; c) falsification of customs and other documents.

The caches are considered to be specially made, equipped or adapted storages, as well as structural tanks, cavities of vehicles, luggage and other items that were previously subject to disassembly, dismantling or re-equipment. Smuggling caches 
with a certain degree of conventionality can be divided into two types: a) specially designed for the hidden movement of contraband, for example, magnetic containers attached to vehicles in hard to reach places; created additional voids, tanks, not provided by the factory design in vehicles (cars, planes, trains); b) specially equipped, adapted for smuggling structural tanks, cavities and other items that were previously disassembled, dismantled or re-equipped (eg, cylinder cavities, air filters, tubular structures).

Analysis of the practice of detecting smuggling in vehicles shows that all sorts of existing and equipped devices are used, cavities in which smuggled items can be hidden. The most common hiding places for contraband items in vehicles are undercarriage and spare wheel tires, specially converted or manufactured fuel and water tanks, tool boxes with double walls and bottoms, space behind the front panel and decorative cab trim, cavities between the cabins, caches, specially equipped in the beams, side members and chassis of the car, etc.

On the railway transport, inter-ceiling spaces, toilets, rubbish bins, heating stoves of carriages, pits for bed linen, hiding places in service compartments, accumulator boxes, lighting plafonds, various niches, seats and backs of sofas, voids in tables, in handrails are most often used for hiding, pre-discharged fire extinguishers, etc. In Poland, for example, a Catalog of Smuggling Hides Used by Sailors on Merchant Ships has been published, describing 500 such places. We believe that in Ukraine it would also be appropriate to prepare similar catalogs of reference nature by type of vehicle, analyzing and using domestic and international experience. The movement of firearms and ammunition through the use of various methods of "physical concealment" is becoming widespread. In this case, "physical concealment" means the creation of conditions under which the visual detection of contraband during customs control is difficult, ie we are talking about other means or methods of physical concealment that complicate the visual detection of objects.

Depending on the objects of customs control, the "other methods of concealment" include the following methods of "physical concealment" of smuggling: a) directly on the smuggler's body; b) in the human body (in the internal cavities and by swallowing); c) directly in clothes, shoes and personal belongings; d) in personal luggage and hand luggage; e) in legal goods and cargoes; f) in vehicles; g) in international postal items (IIP).

The method of concealment is determined by the type of weapon (ammunition), its number, size, weight, as well as the ability to move in disassembled form. When searching for weapons and ammunition, special attention should be paid to: boxes, cases, various packages; glass and porcelain tableware (jars, bottles); plastic thermoses; soft children's and plastic toys; Musical Instruments; food and confectionery; bulk products (cereals, sugar); boxes and packages with washing powder; toilet and laundry soap, etc.

Since firearms, ammunition by their physical nature and structural basis are made of durable metallic materials, have a significant weight, a certain size, characteristic configuration, this leads to their search and detection on the lines of control of hand luggage, baggage with the help of X-ray equipment. Detection of explosive devices in this way is possible in the presence of their components - the time mechanism, current source, a specific type of detonators, thin connecting wires, as well as orange color, as a characteristic feature of organic matter. Firearms and ammunition may be hidden from customs control in the personal luggage and hand luggage of the smuggler, which are with him or follow separately. It can be a double bottom of a suitcase, a backpack, a briefcase (case), bags, voids in their handles, in rubber wheels of a baby carriage, a framework of a backpack, etc. 
Of particular interest is the method of moving the smuggled weapons by duplicating the hand luggage of the smuggler, which is as follows. The smuggler prepares two similar hand luggage (suitcases, travel bags, briefcases). The first hand luggage ("clean", ie without a weapon) the criminal specially leaves in a luggage compartment, and with the second in which the cache is made and the weapon is hidden, it goes on customs control. In the event that the customs officer requires the opening of hand luggage for inspection, the smuggler refuses it and declares that he has identical luggage, and this is someone else's that he took by mistake. After that, in the luggage compartment "is" his own luggage, which he recognizes and presents for control.

In customs practice, it is not uncommon for criminals to conceal by camouflaging contraband items (giving one item the appearance of another). Camouflage is a method of disguise that is used for smuggling and consists in changing the appearance of objects, their appearance: shape, condition, packaging, labels, labels and more. This can be disassembly of objects and separate movement of its components, giving one object (goods) the appearance of others, and so on. For example, a weapon specially adapted for firing can be camouflaged for any household items: a pen, a lighter, a box of cigarettes. In such cases, camouflage is a design of the weapon, which structurally changes its external characteristics, which allows you to refer the weapon to household items. As a rule, such devices are made in the factory by order of special services of foreign countries, so they are very difficult to distinguish in appearance from the usual similar items.

A study of customs practice has shown that the most common ways to move firearms are as follows: a) by transportation by train, sea and air, among the cargo is carefully hidden weapons, they can be hidden in a specially equipped hiding place or in hard to reach places of the vehicle; b) by postal items, the most popular today are the following postal carriers: "Ukrposhta", "Nova Poshta", "In Time", "Delivery", etc.; c) moving personally in hand luggage, suitcase, under clothes, in hidden objects, boxes, etc.; d) via the Internet, etc.

The preparatory actions of the offender begin from the moment he has a criminal plan and the decision to commit smuggling. They combine: selection and study of contraband items; study of the situation in which the offender is to act (collection of information about the place of crossing the border, data on persons carrying out customs control); creating conditions for smuggling (finding customers, determining ways to move items, giving them a different look, forging documents or involving people in order to ensure the unimpeded movement of smuggled items, etc.); choice of method of smuggling, consultation with "specialists"; development of an action plan for smuggling; preparation of means of committing a crime (manufacture, adaptation of caches, forgery of customs and other documents, falsification of containers, packaging); formation and organization of a criminal group (selection and verification of group members, training and their technical support); establishing contact with law enforcement officers to cover up smuggling activities and use their assistance in committing a crime; choosing a way to hide smuggling.

Methods of preparation for the movement of firearms and ammunition are the most common: a) the choice of transport, which will move weapons; b) search for real or forgery of documents (which disguise firearms, hide the identity of the sender (carrier), etc.); c) preparation of camouflage means (models, drawers, boxes, etc.); d) the choice of the place of concealment of weapons in transport; e) study of the route of traffic; f) test shipment of a small part of the weapon; g) study of cargo inspection measures; g) search for persons (usually the elderly or disabled, persons 
who are released from criminal liability) who will agree to transport cargo (firearms) for a fee, etc.

These components are the result of an analysis of smuggling activities in preparation for this type of crime. At the same time, this does not necessarily mean the presence of these components in each specific act of preparation. However, they are of great criminalistic importance, because, as carriers of information about the traces of the crime and other important circumstances of the case, often facilitate the timely detection and detection of smuggling. It should be borne in mind that the detection of smuggling is possible at the stage of preparation, for example, during the purchase of goods (other items) for their further illegal movement across the customs border of Ukraine, making a vehicle hiding place, creating an organized group for smuggling, etc.

The method of concealing the smuggling of firearms and ammunition is implemented when the crime has already been committed, registered and is being investigated. This radically changes the system of factors that determine it. The range of possible actions of a smuggler is significantly expanded and may include intimidation, bribery of witnesses, false testimony, forgery, etc. When smuggling by an organized group of persons, the method of commission may be the same, and the methods of concealment are different for each member of the criminal group. However, a characteristic feature of actions to conceal smuggling is their focus on evading the perpetrator from criminal liability. In addition, the analysis of smuggling activities must take into account the most typical ways of concealing smuggling, namely: destruction, disguise, falsification and concealment.

Thus, the above allows to define the concealment of smuggling of firearms and ammunition as an intentional act of the offender, which is to prevent the establishment of the objective truth about illegal movement across the border by concealing, destroying, masking or falsifying traces of smuggling and smuggling, aimed at guilty of criminal liability. Methods of concealing this type of smuggling are aimed at destroying traces: a) leaving metal particles of firearms, weapons oil, powder gases; b) clothing; c) means of camouflage; d) forged documents, etc.

The generalization and analysis of investigative practice shows that an integral part of the method of smuggling is the use of the results of criminal activity. In the criminalistic aspect, it is essential that even after the end of smuggling, criminal activity continues and is expressed in the use of the results of smuggling. These can be actions, for example, on the sale of smuggled weapons and making a profit, or the use of weapons for their own needs and further criminal activity, and so on. Smuggled weapons are mainly sold directly by the smuggler, with the help of intermediaries (resellers), through criminal structures, relatives or acquaintances. As a rule, it is illegally sold on the "black market" to individual citizens and representatives of organized criminal groups.

Conclusions. Thus, the method of committing a crime is an important element of the criminalistic characterization of the smuggling of firearms and ammunition, which serves as a key to the detection and investigation of this type of crime $[9 ; 10$; $11 ; 12]$. The method of smuggling firearms, ammunition and information about it are the basis for: development of criminalistic characteristics of such crimes[13]; identification of the relationship between the structural elements of the characteristic (method - the identity of the offender, method - traces, method - objects of encroachment, etc.) $[14 ; 15 ; 16]$; construction and promotion of investigative versions and investigation planning; development of features of tactics of carrying out investigative (search) actions[17; 18; 19]; forecasting the mechanism of committing a specific type of smuggling, taking into account the method of commission [20]; 
development of criminalistic prevention of smuggling of firearms and ammunition. Therefore, the study of criminallisticaly significant features of the structural components of the methods of committing the crimes (its preparation, direct commission and concealment) as one of the key elements of criminalistic characteristics create the preconditions and information basis for building an effective methodics for investigating the smuggling of firearms and ammunition.

\section{References:}

[1] Богданович, А.А., Гармаев Ю.П., Диканова Т.А. (1999). Расследование контрабанды. Практ. пособие. М.: Юристь.

[2] Шевчук, В. М. (2019). Сучасний стан та тенденції розвитку криміналістики: актуальні проблеми сьогодення. Проблеми законності, 146, 234-246.

[3] Шевчук, В. М. (2019). Інноваційні напрямки розвитку криміналістики. Інноваційні методи та цифррові технології в криміналістиці, судовій експертизі та юридичній практиці : матеріали міжнар. «круглого столу» (м. Харків, 12 груд. 2019 р.). Харків : Право,142-147.

[4] Журавель, В.А. (2008). Криміналістична характеристика злочинів: проблеми формування та застосування. Вісник Академії правових наук України. Х. : Право, 4 (55), 202-213.

[5] Шевчук, В.М. (2008). Основи методики розслідування контрабанди: Навч. посібник. Харків: Нац. юрид. акад. України, 2001.

[6] Чистова, Л.Е. (2015). Расследование контрабанды наркотических средств, психотропных, сильнодействующих веществ, а также растений, содержащих наркотические средства или психотропные вещества. М.: Юрлитинформ.

[7] Шевчук, В. М. (1998). Проблеми методики розслідування контрабанди: авторефрерат дис... канд. юрид. наук: 12.00.09.; Національна юридична академія імені Ярослава Мудрого, Харків.

[8] Шевчук, B.M. (2020). Проблеми формування та удосконалення окремих криміналістичних методик. Challenges in Science of Nowadays: Proceedings of the 5th International Scientific and Practical Conference (July 16-18, 2020). Washington, USA: EnDeavours Publisher, 117-127.

[9] Шевчук, В.М. (2020). Сучасні наукові концепції фрормування типової структури окремої криміналістичної методики. Юридичний науковийелектроннийжурнал, (4), 359-365.

[10] Шевчук, В. М. (2003). Методика розслідування контрабанди: проблеми теорії та практики: монографрія. Харків.: Гриф.

[11] Постика, И.В. (1998). Проведение дознания по делам о контрабанде, совершенной с участием представителей предпринимательских структур. Одесса: Одеск. госуд. юрид. акад.

[12] Шевчук, В. М. (2002). Обстановка вчинення контрабанди як структурний елемент криміналістичної характеристики. Митна справа: Науково-анал. журн. $з$ питань митної справи та зовнішньоекономічної діяльності, (5), 20-26.

[13] Матусовський, Г.А. (2001). Криміналістична профілактика злочинів, що вчиняються у сфрері підприємницької діяльності, і взаємодія правоохоронних органів. Боротьба зі злочинністю у сфрері підприємницької діяльності. Харків: Право, 249-257.

[14] Шевчук, В. М., Коновалова В. О. (2019). Інноваційні напрями удосконалення криміналістичної методики. Актуальні проблеми боротьби зі злочинністю: проблеми правового захисту. Харків : Право, 351-357.

[15] Шевчук, В.М.(2013). Тактичні операції у криміналістиці: теоретичні засади формування та практика реалізації: монографія. Х.: Вид. агенція «Апостіль», 2013.

[16] Михайлов, В. И., Федоров, А.В. (1999). Таможенные преступления: Учебное пособие. СПб.: Юридический Центр Пресс.

[17] Шевчук, В.М. (1998). Криміналістичні проблеми способу здійснення контрабанди. Проблеми боротьби з корупиією та організованою злочинністю. К.: НДІ «Проблеми людини», 192-195.

[18] Назаров, В.В. (1998). Контрабанда та конфліктні ситуації при її розслідуванні. Боротьба з контрабандою: проблеми та шляхи їх вирішення. К.: НДІ «Проблеми людини», (10), 456-459.

[19] Шевчук, В.М. (2020). Інноваційні криміналістичні продукти у правозастосовній діяльності : поняття, ознаки та проблеми впровадження у практику. Наукові праці Національного університету «Одеська юридична академія». Одеса : Видавничий дім «Гельветика». Том XXVI, 139-155.

[20] Журавель, В.А. (2010). Обставини, що підлягають з'ясуванню, у структурі криміналістичної методики. Теорія та практика судової експертизи та криміналістики: зб. наук. пр. Харків: Право, (10), 12-29. 

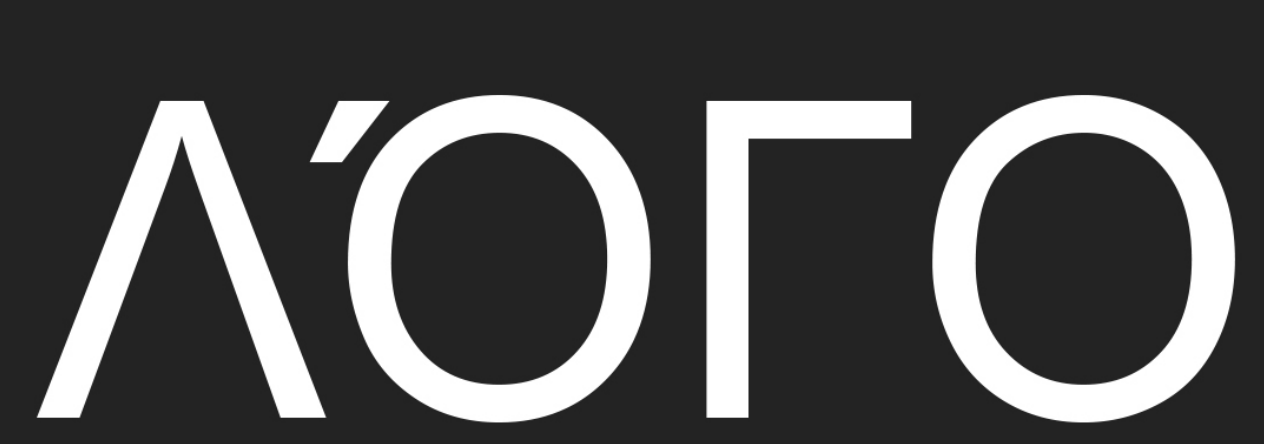

COLEÇÃO DE TRABALHOS CIENTIFICOS

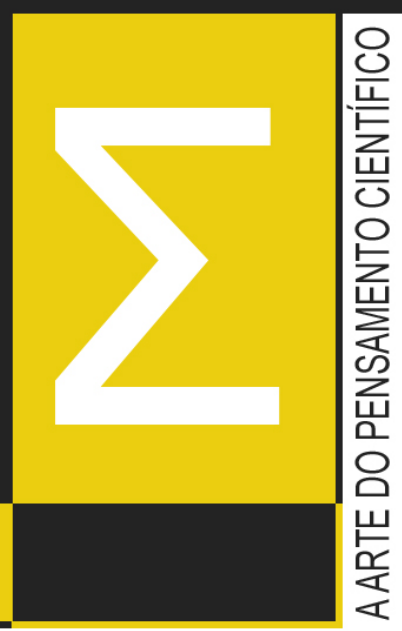

COM MATERIAIS DA CONFERÊNCIA CIENTÍFICO-PRÁTICA INTERNACIONAL

\section{DO DESENVOLVIMENTO MUNDIAL COMO}

RESULTADO DE REALIZAÇÕES EM CIÊNCIA

E INVESTIGAÇÃO CIENTÍFICA

9 DE OUTUBRO DE 2020 • LISBOA, PORTUGAL @
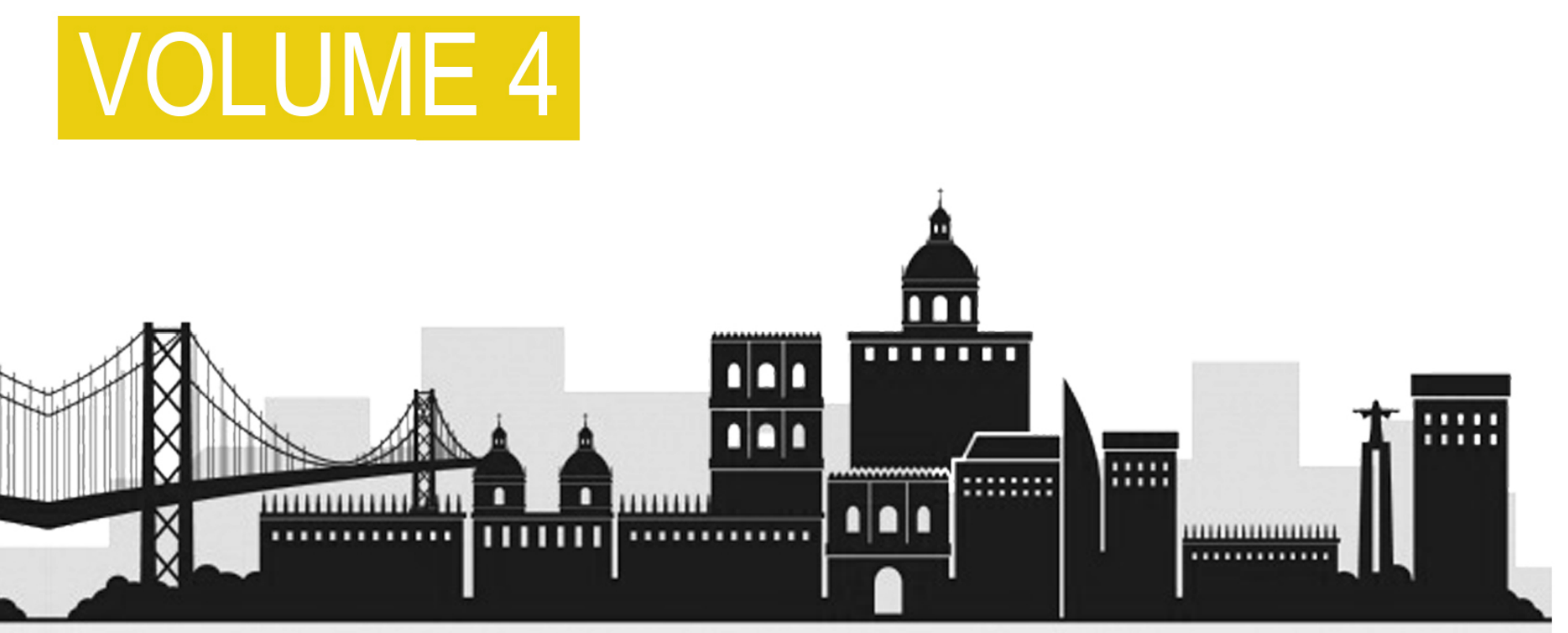

DOI 10.36074/09.10.2020.v4

ISBN 978-972-575-157-2 

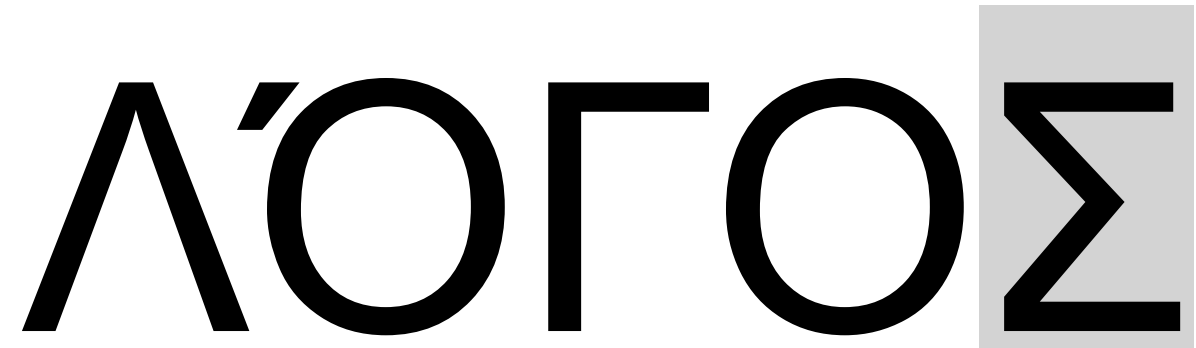

COLEÇÃO DE TRABALHOS CIENTÍFICOS

COM MATERIAIS DA CONFERÊNCIA

CIENTÍFICO-PRÁTICA INTERNACIONAL

«DO DESENVOLVIMENTO MUNDIAL

COMO RESULTADO DE REALIZAÇÕES EM CIÊNCIA E INVESTIGAÇÃO CIENTÍFICA»

9 DE OUTUBRO DE 2020

\section{VOLUME 4}

Lisboa • Portugal 
UDC 001(08)

https://doi.org/10.36074/09.10.2020.v4

D 68

Presidente da comissão organizadora: Holdenblat $M$.

Layout: Bilous T.

Projeto: Bondarenko I.

D 68 Do desenvolvimento mundial como resultado de realizações em ciência e investigação científica: Coleção de trabalhos científicos " $\Lambda$ 'ОГО $\Sigma$ » com materiais da conferência científicoprática internacional (Vol. 4), 9 de outubro de 2020. Lisboa, Portugal: Plataforma Científica Europeia.

ISBN 978-972-575-157-2 («Contexto», Portugal)

DOI 10.36074/09.10.2020.v4

São apresentados os materiais dos participantes da conferência internacional científico-prática multidisciplinar «Do desenvolvimento mundial como resultado de realizações em ciência e investigação científica», que aconteceu em Lisboa em 9 de outubro de 2020.

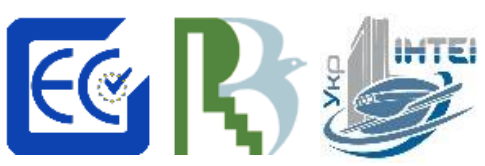

A conferência está incluída no catálogo de conferências científicas internacionais; aprovado pela ResearchBib e UKRISTEI (Certificado № 389 del 16/09/2020); certificado pelo Euro Science Certification Group (Certificado № 22179 del 18/09/2020).

Os materiais da conferência estarão disponíveis ao público sob a Licença Creative Commons Attribution 4.0 International (CC BY 4.0).

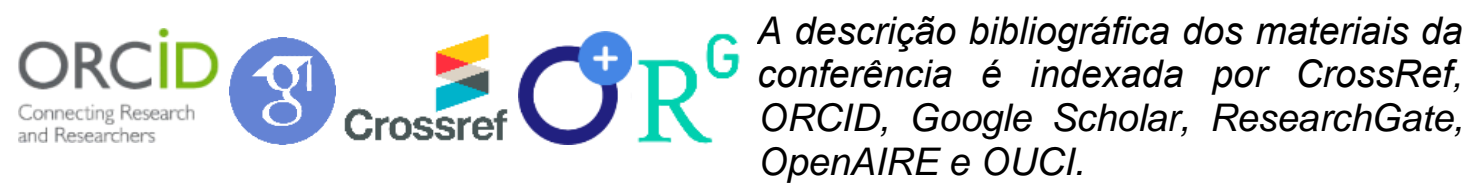

UDC $001(08)$

(c) Participantes da conferência, 2020

(c) Coleção de trabalhos científicos «^'ОГО

(c) Plataforma Científica Europeia, 2020 


\section{CONTEÚDO}

\section{SEÇÃO XVI.}

\section{CIÊNCIAS JURÍDICAS}

A COORDENAÇÃO COMO PRINCÍPIO PARA A CONSTRUÇÃO DE ENERGIA DO ESTADO AO ABRIGO DA LEI CONSTITUCIONAL DE PORTUGAL

Maksurov A.A.

METHODS OF SMUGGLING OF FIREARMS AND AMMUNITION IN THE STRUCTURE OF CRIMINALISTIC CHARACTERISTICS

Shevchuk V., Kotiuk M.

PROBLEMS OF CRIMINALISTIC SUPPORT OF THE PRACTICE OF THE INTERNATIONAL CRIMINAL COURT IN UKRAINE Shevchuk V.

THE IMPLEMENTATION OF DIGITAL CONTRACTS IN UKRAINIAN NOTARY Opanashchuk Y.Y.

АТЕСТАЦІЯ ПРОКУРОРІВ В УКРАЇНІ

Масалітіна В.C.

ДЕЦЕНТРАЛІЗАЦІЯ: ПОНЯТТЯ, ВИДИ, НАСЛІДКИ

Пузаков Д.В.

ДОКАЗОВІ ПРОЦЕСУАЛЬНІ КОНСТРУКЦІЇ У ЦИВІЛЬНОМУ СУДОЧИНСТВІ

Осіпова І.І.

МЕТОДЫ ИССЛЕДОВАНИЯ АДМИНИСТРАТИВНО-ПРАВОВОГО РЕГУЛИРОВАНИЯ СОЦИАЛЬНОЙ ЗАЩИТЫ РАБОТНИКОВ НАЦИОНАЛЬНОЙ ПОЛИЦИИ УКРАИНЫ

Клыпа Е.П.

МІГРАЦІЙНА ПОЛІТИКА В ЄВРОПЕЙСЬКОМУ СОЮЗІ

Притула С.А.

МІСЦЕ ТА ЗНАЧЕННЯ ПОНЯТТЯ АCQUIS ЄС В УГОДІ ПРО АСОЦІАЦІЮ

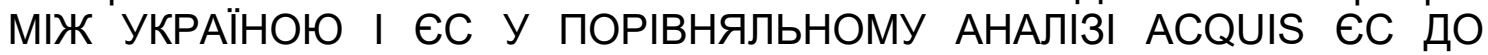
ЗАКОНОДАВСТВА ЄС

Конюх В.В.

НОРМАТИВНІ АСПЕКТИ УПРАВЛІННЯ ВІЙСЬКОВО-ПРОМИСЛОВИМ КОМПЛЕКСОМ ПІСЛЯ ПРОГОЛОШЕННЯ НЕЗАЛЕЖНОСТІ УКРАЇНИ

Ярусевич А.С.

ОБ'ЄДНАННЯ ТЕРИТОРІАЛЬНИХ ГРОМАД В УКРАЇН

Масалітіна В.C. 
4 Do desenvolvimento mundial como resultado de realizações em ciência e investigação científica • Vol.4

ПІДВИЩЕННЯ ЕФЕКТИВНОСТІ ТА УДОСКОНАЛЕННЯ СИСТЕМИ ПУБЛІЧНОГО АДМІНІСТРУВАННЯ У СФЕРІ ТУРИСТИЧНОЇ ДІЯЛЬНОСТІ

Дубов С. М.

ПОСЛУГА ЩОДО НАДАННЯ ІНФОРМАЦІЇ ЯК ПЕРВІСНА КАТЕГОРІЯ ЦИВІЛЬНОГО ПРАВА

Мурач Д.В., Гончарова А.В.

ПРАВОВА РЕГЛАМЕНТАЦІЯ ЕКСТРАДИЦІЇ ЗА КРИМІНАЛЬНИМ ПРОЦЕСУАЛЬНИМ ЗАКОНОДАВСТВОМ УКРАЇНИ

Денисовський М.Д., Томчук І.О., Мельник С.P.

ФУНКЦіЇ ДЕРЖАВИ: ПРОБЛЕМИ ВИЗНАЧЕННЯ

Ткаченко І.М.

ЦИВІЛЬНО-ПРАВОВЕ РЕГУЛЮВАННЯ БЕЗГОТІВКОВИХ РОЗРАХУНКІВ 3 ВИКОРИСТАННЯМ БАНКІВСЬКИХ КАРТОК

Гелецька І.О., Маркевич Р.М. .60

ЩОДО РОЗПОДІЛУ РИЗИКІВ ЯК ФУНКЦІЇ ДОГОВОРУ ПРО НАДАННЯ МЕДИЧНИХ ПОСЛУГ

Горіславська І.В., Тимошенко Л.А.

\section{SECCIÓN XVII.}

\section{CIÊNCIAS HISTÓRICAS}

COMMUNITIES OF THE NEOLITHIC PERIOD IN UZBEKISTAN AND THEIR SOCIAL RELATIONS

Mirsoatova S.T.

FACTORS OF FORMATION AND DEVELOPMENT OF WOMEN'S MOVEMENT IN NADDNIPRYANSK UKRAINE (MIDDLE - THE 80S OF THE 19TH CENTURY)

Motuz V.

KUVA CITY AND ITS ROLE IN FERGHANA CITY PLANNING

Murodova D.H.

PALEOLITHIC PERIOD IN UZBEKISTAN AND THE RELATIONSHIP OF OUR ANCIENT ANCESTORS WITH NATURE

Mirsoatova S.T.

THE HISTORY OF OBIRAHMAT CAVE EXPLORATION

Maxmudova Azizaxon Nosirovna

THE SEL-UNGUR CAVE AND ITS ROLE IN THE PALEOLITHIC PERIOD OF CENTRAL ASIA

Omonov A.M. 
ІНФОРМАЦІЙНО-ДЖЕРЕЛЬНИЙ ПОТЕНЦІАЛ ФОТОГРАФІЙ ВІЙСЬКОВОСЛУЖБОВЦІВ У БІОГРАФІЧНИХ ДОСЛІДЖЕННЯХ

Михайліченко М.А.

«КАР'ЄРНА ДИПЛОМАТІЯ» ЕРНАНА КОРТЕСА У 1504-1528 РОКАХ

Кіктенко О.О., Каріков С.А.

ЛИСТ О. МИХАЙЛА ЗУБРИЦЬКОГО ДО «НАРОДНОЇ РАДИ»

Тугай М.I.

ПРАВЛІННЯ ІМПЕРАТРИЦІ ЗОЇ В ВІЗАНТІЙСЬКІЙ ІМПЕРІЇ (1028-1050РР.)

Кладова А.А. .88

\section{SECCIÓN XVIII. GEOGRÁFIA}

РЕГІОНАЛЬНИЙ ЛАНДШАФТНИЙ ПАРК «МАЛЬОВАНКА»: ОЦІНКА РЕКРЕАЦІЙНОГО ВИКОРИСТАННЯ ТЕРИТОРІЇ

Царик Л.П., Царик П.Л., Кузик І.Р. .90

\section{SECCIÓN XIX.}

\section{ANTROPOLOGIA E ARQUEOLOGIA}

ANTHROPOGENIC LANDSCAPES AND THEIR ARCHAEOLOGICAL STUDY IN THE PROCESS OF URBANIZATION

Murodova D.H.

ARCHEOLOGY OF THE CENTRAL FERGANA STONE PERIOD

Axmadaliyeva Ra'noxon O'rinboy qizi

ОЧАГИ КАК КУЛЬТОВЫЕ СООРУЖЕНИЯ ОГНЕПОКЛОННИКОВ (ПО МАТЕРИАЛАМ АРХЕОЛОГИЧЕСКИХ ИССЛЕДОВАНИЙ)

Мамиров О.У. 


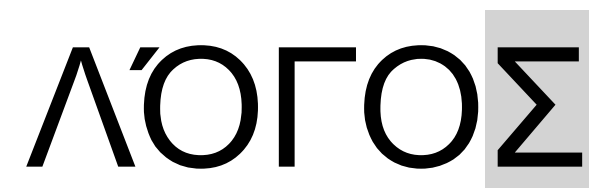

COLEÇÃO DE TRABALHOS CIENTÍFICOS

\title{
COM MATERIAIS DA CONFERÊNCIA CIENTÍFICO-PRÁTICA INTERNACIONAL \\ «DO DESENVOLVIMENTO MUNDIAL COMO RESULTADO DE REALIZAÇÕES EM CIÊNCIA E INVESTIGAÇÃO CIENTÍFICA»
}

9 de outubro de 2020 • Lisboa, Portugal

\author{
VOLUME 4
}

em ucraniano, russo, inglês e português

Todos os materiais foram revisados

A comissão organizadora nem sempre compartilha a posição dos autores

Os autores são responsáveis pela exatidão do material apresentado

Assinado para impressão em 09.10.2020. Formato 60×84/16.

Papel offset. Fonte Arial. Impressão digital

Folhas impressas condicionalmente 6,28.

Circulação: 100 exemplares.

Impresso a partir do layout original acabado.

Informações de contato do comitê organizador:

21037, Ucrânia, Vinnytsia, rua Arquitetos, 18, escritório 81

NGO «Plataforma Científica Europeia»

Telefones: +38 098 1948380; +38 0981956755

E-mail: info@ukrlogos.in.ua

URL: www.ukrlogos.in.ua 